\title{
Partial Characterization of Bermuda, Carabao, Cogon and Talahib Grass Pollen Extracts
}

\author{
Mary Anne R. Castor, ${ }^{1}$ Madeleine W. Sumpaico, ${ }^{1}$ Ronald R. Matias ${ }^{2}$ and Leonora A. Geniston ${ }^{2}$
}

${ }^{1}$ Section of Allergy and Immunology, Department of Pediatrics, College of Medicine and-Philippine General Hospital, University of the Philippines Manila ${ }^{2}$ Biological Science Department, United Laboratories, Inc., Mandaluyong City, Philippines

\begin{abstract}
Background. Grass pollen grains are important causes of respiratory allergies. The Philippines has a different grass flora compared to that of western countries, so pollen extracts have to be processed for use in the diagnosis and treatment of respiratory allergies. The local pollen extracts available in clinical practice have not yet been characterized, which is important in improving extract quality.
\end{abstract}

Objectives. This study aims to perform physicochemical characterization through protein content determination and gradient sodium-dodecyl sulfate polyacrylamide gel electrophoresis (SDS-PAGE) of extracts from four grasses: Cynodon dactylon (bermuda grass), Axonopus compressus (carabao grass), Imperata cylindrica (cogon), and Saccharum spontaneum (talahib) and immunologic characterization by identifying its IgE-binding component through immunoblot.

Methods. This is a descriptive study. The pollen grains were processed into allergen extracts and protein contents were determined. The extracts were separated by gradient SDS-PAGE and subjected to immunoblotting. Bands were visualized using Fluorchem C2 aided with Alpha View Software.

Results. Total protein in the pollen extracts ranged from 281.3$968.61 \mu \mathrm{g} / \mathrm{ml}$. Protein bands of bermuda were in the 14.4-66.3 $\mathrm{kDa}$ range, carabao grass at $3.5-66.3 \mathrm{kDa}$, cogon at $3.5-200 \mathrm{kDa}$, and talahib at $21.5-66.3 \mathrm{kDa}$. A single IgE-binding protein band was seen on immunoblot at $55.4 \mathrm{kDa}$ using a single serum sample.

Conclusion. Protein contents of the allergen extracts vary. The molecular weights of the different protein bands seem to correspond to known groups of grass pollen allergens. There was only one lgE-binding protein band seen on preliminary immunoblot.

Key Words: grass pollen allergy, pollen characterization, bermuda grass, carabao grass, cogon, talahib

\footnotetext{
Corresponding author: Mary Anne R. Castor, MD

Section of Allergy and Immunology

Department of Pediatrics

Philippine General Hospital

University of the Philippines Manila

Taft Avenue, Ermita, Manila, 1000 Philippines

Telephone: +6328223567

Email: mrcastor@up.edu.ph / annecastor@yahoo.com
}

Introduction
The prevalence of allergy has been increasing worldwide. In the International Study of Allergy and Asthma in Children (ISAAC), the Philippines was shown to have a higher prevalence of atopic diseases compared with some of our neighboring countries in Southeast Asia. ${ }^{1}$ Filipinos in Metro Manila, aged 13 to14 years, had one of the highest prevalence of allergic rhinitis at $32.5 \%$; asthma prevalence was at $17.6 \% .^{2}$ In the 2008 National Nutrition Health Survey (NNHeS), the over-all prevalence of allergic rhinitis among Filipino adults was reported to be $20 \%{ }^{3}$ while that of asthma was at $8.7 \%{ }^{4}$

Allergic diseases are generally caused by $\operatorname{IgE}$ recognition of harmless antigens, called allergens, and the subsequent activation of cells of the immune system, leading to release of mediators and subsequent allergic symptoms. Windborne plant pollen grains are important causes of allergies as they are one of several allergens present in the outdoor environment. The dramatic appearance of windborne pollens, and resulting symptoms, are familiar events for physicians and laypersons alike. A local study showed that the distribution of the average monthly asthma consults followed the pattern of the monthly total pollen counts. ${ }^{5}$

Grass pollen is the major cause of pollinosis in many parts of the world. ${ }^{6}$ In Europe, America, and Australia up to $70 \%$ of patients with type I allergy display IgE reactivity to grass pollen allergens. ${ }^{7}$ In the Philippines, grasses were also reported to be the most predominant pollen grains in the atmosphere with perennial pollination. $8,9,10$

Pollen extracts are important in the diagnosis and treatment of pollen allergies. These extracts are used for skin testing and specific allergen immunotherapy. Local pollen extracts have to be prepared because the flora of foreign countries is different from that of the Philippines. The precision of diagnosis and efficacy of immunotherapy depends on the quality of extracts used. ${ }^{11}$

Extracts of allergens contain varying amounts of individual allergens with different immunogenicity. ${ }^{12}$ At present the grass pollen extracts used at the Allergy Clinic of the Philippine General Hospital and by majority of allergists in the country are crude extracts (complex mixture of allergenic and non-allergenic molecules) which have not yet 
been characterized. Active ingredients in allergen extracts are the proteins which the immune system reacts to or the allergenic molecules. The purpose of allergen characterization is to be able to describe these allergenic proteins or molecules. Mari A, the creator of the Allergome platform, a database of allergens, lists the steps of allergen identification and characterization in the pre-allergenic structure definition (from a crude pollen extract to the identification of the allergenic pollen molecule) as follows: 1) suspicion of an allergic reaction to an organism or its tissue (eg. pollen); 2) preparation of the best extract starting from the best raw material; 3) positive skin test and immunoglobulin-E (IgE) testing with the extract; 4) extract evaluation by sodium-dodecyl sulfate polyacrylamide gel electrophoresis (SDS-PAGE); 5) IgE immunoblot identification of SDS-PAGE isolated bands; and 6) isolation and preliminary sequencing of the IgE-reactive bands. ${ }^{13}$ Since these pollen extracts are already used for skin testing in clinical practice, this study will deal with steps 4 and 5 .

Characterization of allergens involves both physicochemical and immunological characterization. The most popular and most common technique for physicochemical characterization is through SDS-PAGE ${ }^{14}$ where a heterogeneous allergen or a crude extract is separated into individual proteins with different molecular weights. A set of protein markers with known molecular weights are used to identify the molecular weight of the individual allergens in the extract. This is usually followed by immunologic characterization which identifies the IgEbinding protein or the protein to which the immune system reacts to. ${ }^{13}$ In the immunoblot procedure, the separated proteins from the SDS-PAGE are transferred by diffusion to a nitrocellulose membrane. Serum from an allergic patient is added. The IgE antibodies in the serum will bind to the allergen. This is followed by the addition of a second antiIgE antibody which is conjugated to an enzyme. A color change is produced with the addition of a substrate. The band where this color change occurs corresponds to the IgEbinding protein. Further physicochemical characterization may be done with isoelectric focusing to determine the $\mathrm{pI}$ range of the proteins and glycoprotein detection using Periodic acid-Schiff (PAS) technique to identify glycoproteins. X-ray crystallography can be done to determine the 3D structure of the allergen, particularly when planning to develop recombinant allergens. ${ }^{14}$ Hence, from a crude pollen extract, allergenic molecules can be identified, the presence and amount of which can ensure the quality and batch to batch consistency of the manufactured extracts.

Effective diagnosis and treatment of allergic diseases requires the optimal amount of the allergenic molecule in the allergen extracts for skin testing and the maintenance dose for immunotherapy. The $\mathrm{WHO}$ and regulatory government agencies in some countries recommend that allergen manufacturers state the content of major allergens of their extracts. ${ }^{15}$ The identification of the allergenic molecule can be the basis later on for cross-reactivity studies, allergen standardization, or the production of recombinant allergens. These are parts of the steps in the post-allergenic structure definition (after the allergenic molecule has been identified) in the full characterization process. ${ }^{13}$

Cross-reactivity studies are important since most grass pollen types show a very high degree of cross-reactivity. ${ }^{6,16}$ Cross-reactivity is present when an $\operatorname{IgE}$ antibody against an allergen will also react with other allergens. The determination of allergen cross-reactivity among the grass pollen extracts will reduce the number of extracts used in skin testing and immunotherapy, since a representative member can generally provide efficacy against the entire group. In the United States, temperate pasture grasses share major allergens, ${ }^{17}$ so they use only a representative member for the group. A study in the Netherlands showed that one grass species is sufficient for in vitro diagnosis of grass pollen allergy. ${ }^{18}$ Lack of information on cross-reacting allergens may also increase the likelihood of adverse reactions due to inadvertent dosing with greater amounts of the same allergen. ${ }^{19}$

Allergen standardization is recommended in order to improve extract quality. Current standardization requirements focus on the consistency of production and the safety and potency of allergen products. It ensures that skin test reactions are large enough to suggest clinical sensitivity but not so large as to produce excessive discomfort or the risk for a serious systemic reaction. ${ }^{15}$

The use of recombinant allergens is an alternative approach to improve safety and efficacy of specific immunotherapy. ${ }^{15}$ It is also recommended when the amount of allergenic molecule in the extract is very low ${ }^{13}$ especially for production purposes.

The World Health Organization (WHO) - International Union of Immunological Societies (IUIS) Allergen Nomenclature Subcommittee has proposed a unified nomenclature system for highly purified allergens and individual components identified within complex allergenic mixtures by means of various immunochemical and physiochemical separation techniques. ${ }^{20}$ The subcommittee maintains an allergen database that contains approved and officially recognized allergens. ${ }^{21}$ Another database is that of the Allergome platform ${ }^{22}$ which contains more allergens. The WHO-IUIS database lists only submitted proteins that have fulfilled a stringent criteria ${ }^{23}$ while the Allergome database requires only that the molecule be tested at least once for its IgE-binding capacity or that it has any structural relationship with known allergens. ${ }^{14}$ Lowenstein has defined the term "major allergen" as "antigens which bind IgE from at least 50 percent of the sera of patients tested and show strong binding to at least 50 percent of these"; a more appropriate description of the antigens would be "major IgE-binding antigens" ${ }^{24}$ 
Studies on characterization of pollen extracts of Philippine grasses are few in number. While our western counterparts are already into recombinant pollen allergens and standardization of some of them, we have hardly characterized our local pollen. There is a need to do characterization studies because our flora, being a tropical country, differs from theirs.

\section{Objectives}

1. To process allergenic pollen extracts of Cynodon dactylon (bermuda), Axonopus compressus (carabao grass), Imperata cylindrica (cogon), and Saccharum spontaneum (talahib) and determine their protein contents.

2. To characterize the physicochemical properties of the protein components (protein profile) of these extracts using gradient SDS-PAGE.

3. To identify the IgE-binding proteins of the four Philippine grass pollen extracts through immunoblotting.

\section{Methods}

\section{Preparation of Pollen Extracts and Protein Determination}

The pollen samples were collected by a pollen farmer. The pollen batches used throughout the work contained $>80 \%$ purity, determined through visual inspection of a sample under the microscope.

Six (6) grams of pollen from bermuda grass, carabao grass, cogon, and talahib were defatted by adding $40 \mathrm{ml}$ of diethyl ether (JT Baker). Serial defatting was done by subjecting the mixtures to rotary shaking at room temperature for 8 hours for the first extraction, and overnight for the second extraction. The pollen mixtures were centrifuged at 3,000 rpm for 15 minutes after rotary shaking.

Forty (40) $\mathrm{ml}$ of $1 \mathrm{X}$ phosphate buffered solution (PBS) $\mathrm{pH} 7.3$ (with $0.3 \%$ protease inhibitor) was added to the defatted pollen to extract the pollen antigen by continuous rotary shaking overnight inside the refrigerator. After shaking, the samples were centrifuged at 12,000 rpm for 30 minutes using Sorvall Refrigerated Centrifuge (DuPont Instruments). The extracted allergen was weighed and stored in $-70^{\circ} \mathrm{C}$ before lyophilization. The protein content was determined by the Bradford Method (BioRad).

\section{Gradient SDS-PAGE}

Gradient SDS-PAGE was carried out in 4\% stacking gel and $10 \%$ to $15 \%$ resolving gel aided with tris-glycine buffer ( $\mathrm{pH} 7.4$ ).

Lyophilized samples in 2X SSB solution were boiled for 1 minute and centrifuged at 90,000 rpm for 20 minutes using Beckman Optima TL Ultracentrifuge. An aliquot of $15 \mu \mathrm{l}$ of the samples was loaded onto the gel with Mark 12 Unstained Standard (Invitrogen) as marker. Electrophoresis was carried out at $150 \mathrm{~V}, 15 \mathrm{~mA}$. The gel was visualized by using SilverXpress Kit (Invitrogen).

\section{Immunoblot (Western Blot)}

Protein bands separated from gradient SDS-PAGE were electrophoretically transferred to Transblot Transfer Medium nitrocellulose membrane (BioRad) using the semidry blotting method (Westermier, 2001). After blotting for 2.5 hours, the bands were stained by $10 \%$ India ink and visualized using Fluorchem C2 aided with Alpha View Software (Alpha Innotech). The unbound sites on the nitrocellulose membrane were blocked by incubation with 3\% BSA for 3 hours. After washing, the membrane was incubated overnight with 1:2 serum in $0.1 \%$ PBS-Tween with constant agitation using Orbitron Rotator II (Boekel) and washed. The membrane was incubated with 1:250 antihuman IgE (peroxidase conjugated) in 0.1\% PBS-Tween for 1 hour at $37^{\circ} \mathrm{C}$. Diaminobenzidine (DAB) (Sigma) was used as the substrate for color development. After successive washings, the bands were detected using the aforementioned method.

\section{Results}

\section{Pollen Extract Protein Content Determination}

The total protein in the crude pollen extracts ranged from 281.3 to $968.61 \mu \mathrm{g} / \mathrm{ml}$, with the lowest concentration in bermuda grass, and the highest concentration in talahib as shown in Table 1.

Table 1. Protein concentrations of allergenic extracts from bermuda grass, carabao grass, cogon and talahib

\begin{tabular}{cc}
\hline Pollen Source & Protein concentration $(\mu \mathrm{g} / \mathrm{ml})$ \\
\hline Bermuda grass & 281.13 \\
Carabao grass & 439.20 \\
Cogon & 766.53 \\
Talahib & 968.61 \\
\hline
\end{tabular}

\section{Gradient SDS-PAGE}

The blotting of the separated proteins on gradient SDSPAGE and nitrocellulose membrane is shown in Figures 1 and 2, respectively. The molecular weights of the proteins in the bermuda grass pollen extract ranged from 14.4 to 66.3 kilodaltons (kDa) (Figures 1 and 2, lane 1) as determined by SDS-PAGE. The carabao grass extract had protein sizes ranging from 3.5 to $66.3 \mathrm{kDa}$ (Figures 1 and 2, lane 2). On the other hand, the protein sizes in the cogon extract ranged from 3.5 to $200 \mathrm{kDa}$ (Figures 1 and 2, lane 3). Lastly, the molecular weights of the proteins in the talahib extract ranged from 21.5 to $66.3 \mathrm{kDa}$ (Figures 1 and 2, lane 4). The common bands among the four grasses were between 55.4 and $66.3 \mathrm{kDa}$, and between 21.5 and $31.0 \mathrm{kDa}$. The talahib extract had the least number of bands (only 2) and the cogon extract had the most number of bands. 


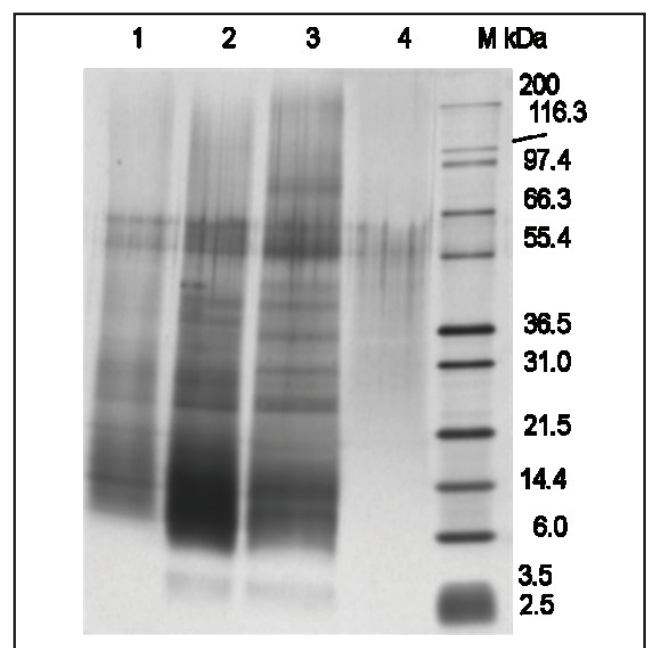

Figure 1. Silver-stained SDS-PAGE of allergen extracts from bermuda grass, carabao grass, cogon and talahib (Lanes: $1=$ bermuda grass, 2 = carabao grass, $3=$ cogon, $4=$ talahib, $M=$ marker).

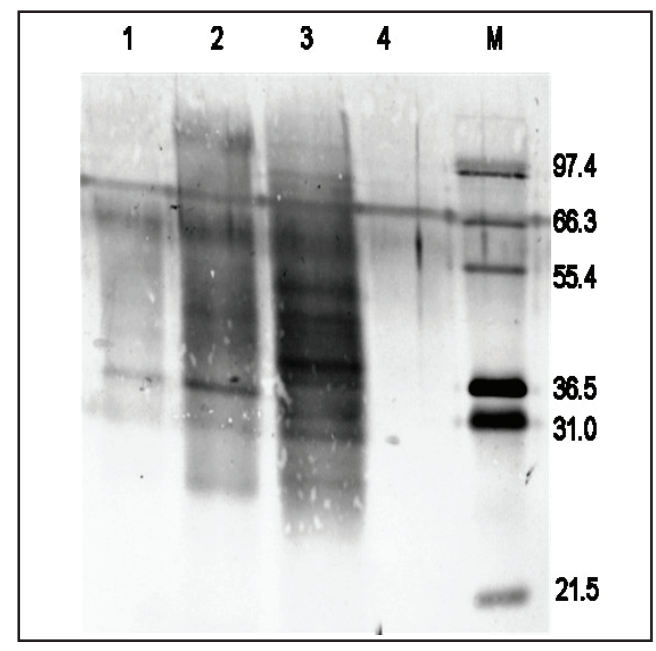

Figure 2. India ink-stained blot on nitrocellulose membrane of separated proteins of extracts from bermuda grass, carabao grass, cogon and talahib. (Lanes: $1=$ bermuda grass, $2=$ carabao grass, $3=$ cogon, $4=$ talahib, $\mathrm{M}=$ marker).

Immunoblot (Western Blot). The protein fraction of both bermuda grass and cogon between 55.4 and $66.3 \mathrm{kDa}$ were reactive to the serum of the volunteer with positive skin prick test to bermuda grass and cogon (Figure 3).

\section{Discussion}

Grasses, collectively, accounted for $72 \%$ of the outdoor allergens with positive skin test results in the clinic. ${ }^{25}$ An older study showed that $26 \%$ of Filipino patients were allergic to grasses based on skin test results. ${ }^{26}$ In selecting appropriate pollen extracts for clinical use, the combination of extensive prevalence in the air and accompanying allergic symptoms during peak pollen counts is the best indicator of its potential importance.

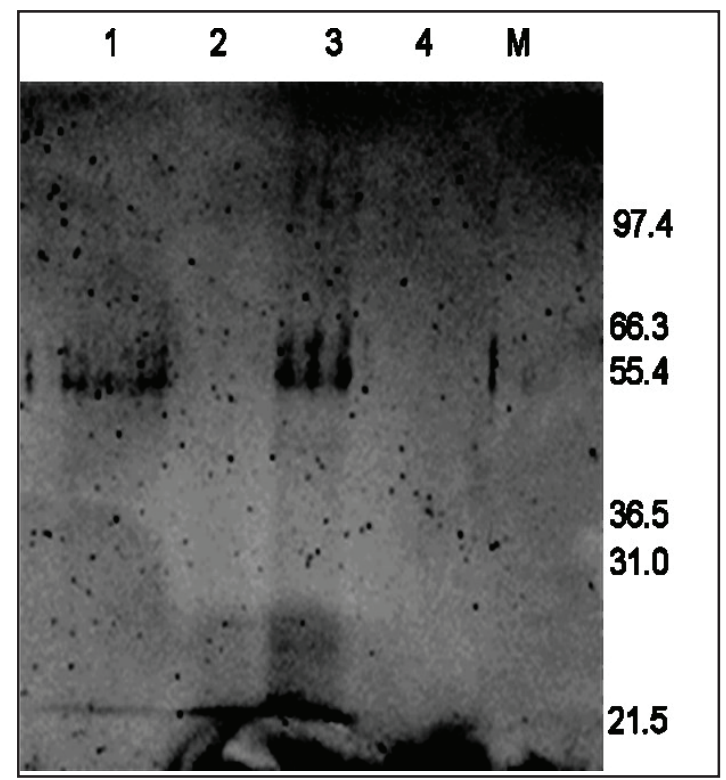

Figure 3. Specific-IgE binding fractions detected by immunoblotting from bermuda grass, carabao grass, cogon and talahib visualized by diaminobenzidine (Lanes: 1 = bermuda grass, 2 = carabao grass, $3=$ cogon, $4=$ talahib, $\mathrm{M}=$ protein marker).

Radauer et al, in 2006, reported that the Allergome database had 178 plant species that contained pollen to which allergic reactions have been described. These plants belonged to 44 taxonomic families and 29 orders. About $1 / 4$ of these allergenic pollen species were grass pollens (Poaceae, 43 species). ${ }^{27}$

Four of the most common grass pollen grains were included in this study; they were the pollen grains available with the highest purity $(>80 \%)$ at the Section of Allergy and Immunology at the time of this study. Grasses belong to the Poaceae family (also known as the Gramineae) which is a large and nearly ubiquitous family of monocot flowering plants. Cynodon dactylon or bermuda grass belongs to the subfamily Chloridoideae, tribe Chlorideae and is believed to have originated in Turkey and Pakistan and has been introduced to tropical and subtropical, as well as some temperate regions. ${ }^{28}$ It is an extensively creeping, much-branched perennial grass with underground rhizomes. Its leaves are small, linear, 2 to $10 \mathrm{~cm}$ long, up to $4 \mathrm{~mm}$ wide; its inflorescence are terminal, 4 to 5 slender digitate spikes, 1 to $6 \mathrm{~cm}$ long, 1 to $2 \mathrm{~mm}$ wide, each bearing many spikelets (Figure 4A). ${ }^{29}$ A bermuda grass pollen measures around $26.37 \pm 0.18 \mu^{30}$ and is shown in Figure 5A.

Axonopus compressus (Paspalum), locally known as carabao grass, also called carpet grass, belongs to the Panicoideae subfamily and is widely naturalized in the 
tropics and subtropics, including the Philippines and the Pacific Islands. ${ }^{28}$ It is a creeping prostrate perennial, rooting at the nodes, with slender leafy, erect flowering systems, up to $60 \mathrm{~cm}$ high. Leaves are blade-thin, flat or folded, linearlanceolate, 5 to $15 \mathrm{~cm}$ long. Its inflorescence consists of 2 terminal spike-like very slender branches, 10 to $15 \mathrm{~cm}$ long, 1 $\mathrm{mm}$ wide, with 2 rows of yellowish flattened overlapping spikelets along the underside of the spikelets (Figure 4B). ${ }^{29}$ Its pollen is shown in Figure 5B. A description of the morphology of a carabao grass pollen was not included in the study of Concepcion-Garcia.

Imperata cylindrica, commonly known as cogon, is native to Asia and is common in the humid tropics but can also be found in warmer temperate areas. It is a compact loosely growing perennial grass, 15 to $120 \mathrm{~cm}$ high. Its leaves are linear-lanceolate, up to $150 \mathrm{~cm}$ in length, 4 to $18 \mathrm{~mm}$ wide; its inflorescence consists of panicles which are dense and spike-like, 3 to $20 \mathrm{~cm}$ long, with creamy-white or silverywhite silky hairs (Figure 4C). ${ }^{29}$ A cogon pollen measures $32.57 \pm 0.22 \mu^{30}$ and is shown in Figure 5C.

Saccharum spontaneum, locally known as talahib, is a perennial grass native to south Asia. It grows up to three meters in height, with spreading rhizomatous roots. ${ }^{28}$ It is coarse and erect with narrow blades, acuminate, 0.5 to $1 \mathrm{~m}$ long; its inflorescence has a lanceolate panicle, white, 20 to $60 \mathrm{~cm}$ long, $5 \mathrm{~cm}$ wide; the axis below, branches short with long hairs; racemes are whorled, each with alternate pairs of spikelets 3 to $3.5 \mathrm{~mm}$ long (Figure 4D). ${ }^{29}$ Its pollen size is $37.31 \pm 0.46 \mu .{ }^{30}$ See Figure 5D for the pollen photograph.

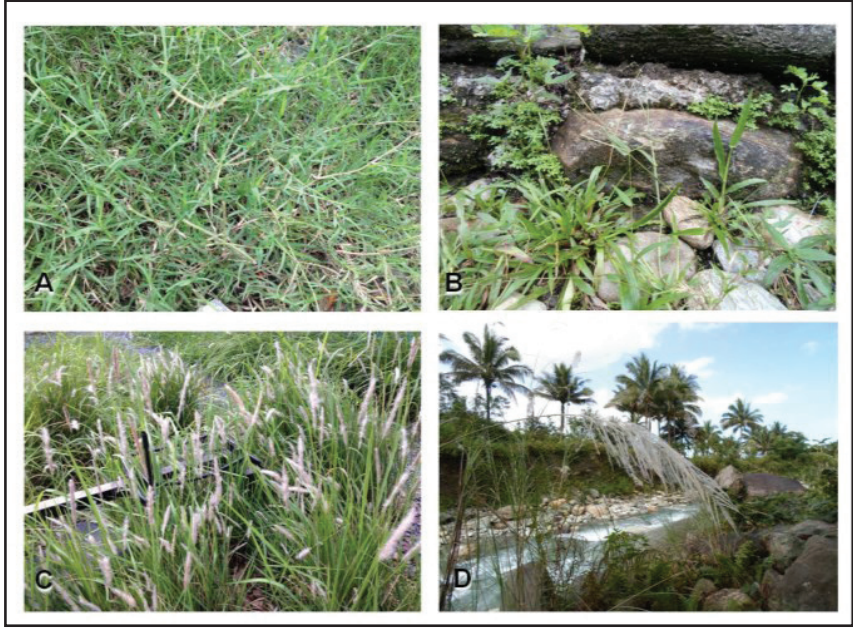

Figure 4. Photographs of common local grasses (A. Bermuda grass B. Carabao grass, C. Cogon, D. Talahib).

Over the last decades there have been large advances in the molecular characterization of pollen allergens. Plant families with the largest number of sequenced allergens were in the Poaceae family (71 allergens from 15 species). To date, however, current knowledge of pollen allergens is concentrated on major allergen sources of Europe, North America, and Japan. The increase of allergic diseases, especially in Asia, emphasizes the need for molecular characterization of tropical and subtropical pollen species. ${ }^{26}$ There have been few studies on pollen allergens in the Philippines and most of these were done in the 1950s to the 1980s, with one study done in $2012 .{ }^{31}$

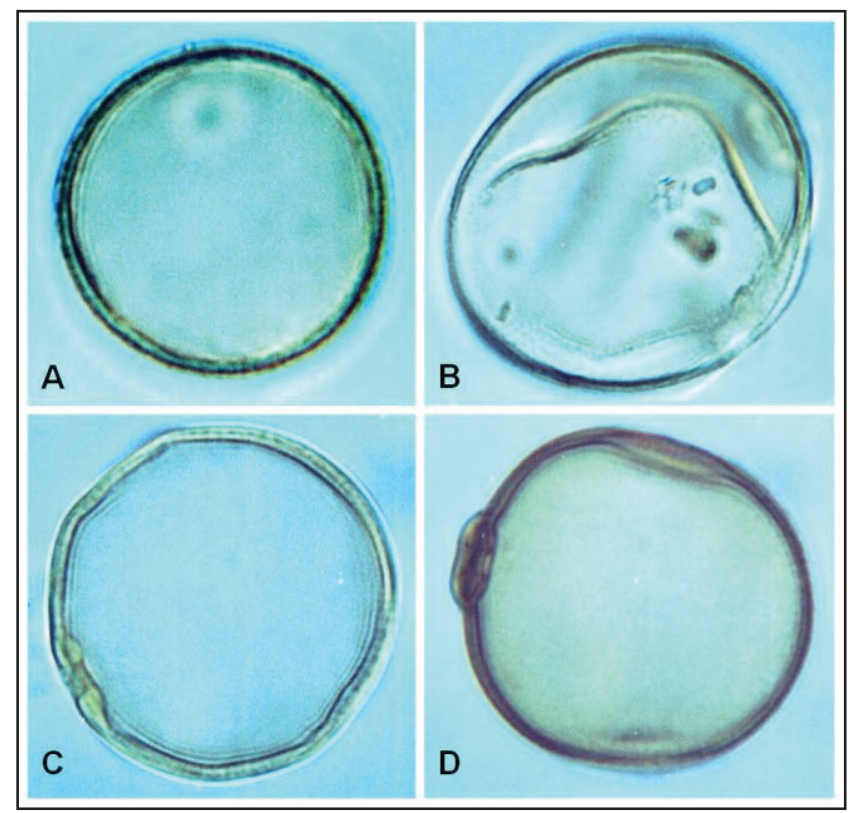

Figure 5. Photomicrographs of pollen taken under the microscope (A. bermuda grass, B. carabao grass, C. cogon, D. talahib) indicate magnification.

The protein content of the processed pollen extracts ranged from 281.3 to $968.61 \mu \mathrm{g} / \mathrm{ml}$. The protein content would correspond to both allergenic and non-allergenic molecules in the extract. Talahib had the highest protein content with bermuda grass having the lowest. The study by Cabauatan and Ramos yielded very high protein content at 11 to $22 \mathrm{mg} / \mathrm{ml}(11,000$ to $22,000 \mu \mathrm{g} / \mathrm{ml}) .{ }^{31}$ The protein content in our study is closer to the results of the study of Sander et al. when they determined the protein concentrations of skin prick test solutions. Their protein concentrations ranged from 15 to $427 \mu \gamma / \mu \lambda .{ }^{32}$ In their study, they found a correlation between protein content, allergen concentration and major allergen content in the extracts. ${ }^{32}$ These are extracts manufactured in Europe where the major allergens are known.

The low amount of allergenic material available often hinders basic allergy research. In this study, however, despite the varied protein contents, each extract was capable of being resolved into different protein components in the gradient SDS-PAGE. Bermuda grass, which had the lowest protein content, even had more bands compared to talahib which had the highest protein content. 
The resolved protein components would likely correspond to known grass allergen groups. Fourteen grass allergen groups have been fairly well characterized (Table 2): groups 1, 2/3 (groups merged), and 5 (old group 9) are major allergens. Group 1 allergens are $\beta$-expansins, papain-related cysteine proteinases. Group 4 grass pollen allergens represent glycoproteins with a molecular weight of 50 to 60 $\mathrm{kDa}$, which are present in many grass species. Older work demonstrated homology within group 1 allergens and to group 2/3 allergens; additionally, T-cell epitopes are shared between groups 1 and 5 allergens. ${ }^{33}$ Group 1 allergens, with a molecular weight of approximately $30 \mathrm{kDa}$, react to $\mathrm{IgE}$ antibodies in more than $95 \%$ of patients allergic to grass pollens. Group 2/3 allergens of 10 to $12 \mathrm{kDa}$ molecular weight are recognized by $\mathrm{IgE}$ antibodies of approximately $60 \%$ of patients allergic to grass pollen; $70 \%$ of patients allergic to grass pollen react with group 4 allergens at 50 to $60 \mathrm{kDa} ; 70 \%$ to $80 \%$ of patients react with group 5 allergens; and $20 \%$ display IgE reactivity to profilins at $14 \mathrm{kDa}$. Group 6 allergens with a molecular weight of $10 \mathrm{kDa}$ share $\operatorname{IgE}$ epitopes with group 5 allergens and are expressed in certain grass species only. ${ }^{34}$ Based on Lowenstein's definition, group 4 allergens can also be considered as a major allergen.

Table 2. Molecular weights of the different groups of grass pollen allergens

\begin{tabular}{cc}
\hline Allergen & Molecular Weight (kDa) \\
\hline Group 1 & $25-35$ \\
Group 2/3 & $10-12$ \\
Group 4 & $40-60$ \\
Group 5 & $25-35$ \\
Group 6 & $\sim 10$ \\
Profilin & $\sim 14$ \\
\hline
\end{tabular}

The molecular weights of the proteins in the bermuda grass pollen extract ranged from 14.4 to $66.3 \mathrm{kDa}$ on gradient SDS-PAGE (Figure 1). The study by Cabauatan and Ramos had bands ranging from 4.6 to $72 \mathrm{kDa} .{ }^{31} \mathrm{~A}$ study by Chang et al showed at least 8 antigenic components of bermuda grass with molecular weights ranging from 12 to $200 \mathrm{kDa}{ }^{35}$ Our study was not able to pick up the higher molecular weight bands. Another study, which used 2D gel and immunoblot techniques, showed about 230 proteins in bermuda grass, 65 of which are IgE-binding proteins. Some of these bands were presumed to be isoforms or the degraded products of allergen. ${ }^{36}$ The differences in the results in the different studies could be due to the methods and laboratory techniques used.

There was a prominent band in the bermuda grass extract at the $36.5 \mathrm{kDa}$ upon transfer to nitrocellulose membrane (Figure 2). This may correspond to the group 1 or group 5 allergen of grasses with molecular weights ranging from 25 to $35 \mathrm{kDa}$ (Table 2) and, possibly, the major allergen in bermuda grass, Cyn d 1, which has a molecular weight of $32 \mathrm{kDa}$ [listed in the WHO-IUIS database] (Table 3). Cyn d 1 belongs to the group 1 grass allergens. It presently consists of 11 isoforms..$^{22}$ The Allergome database lists 33 allergens and isoforms for bermuda grass while the WHO-IUIS database lists only 7 allergens.

Table 3. Known allergens in Cynodon dactylon (bermuda grass) from the WHO/IUIS Allergen Nomenclature Subcommittee Database

\begin{tabular}{lcc}
\hline Allergen & Biochemical Name & $\begin{array}{c}\text { Molecular Weight } \\
(\mathbf{k D a})\end{array}$ \\
\hline Cyn d 1 & B-expansin & 32 \\
Cyn d 7 & Polcalcin & 12 \\
Cyn d 12 & Profilin & 14.5 \\
Cyn d 15 & - & 9 \\
Cyn d 22w & Enolase & - \\
Cyn d 23 & - & 9 \\
Cyn d 24 & Pathogenesis-related protein PR-1 & 21 \\
\hline
\end{tabular}

There was also a light stained band, still from the bermuda grass extract, at $55.4 \mathrm{kDa}$ seen at the nitrocellulose membrane (Figure 2). This does not correspond to any of the known allergens of bermuda grass but it probably belongs to the group 4 grass allergen with molecular weight range of 40 to $60 \mathrm{kDa}$.

Carabao grass had protein components ranging from 3.5 to $66.3 \mathrm{kDa}$ on gradient SDS-PAGE (Figure 1). No studies on carabao grass characterization were found on literature search. There were also no known allergens listed in both the WHO-IUIS and the Allergome databases. Dark bands were clumped in the $<20 \mathrm{kDa}$ area and these would likely correspond to groups $2 / 3$, group 6 , and/or profilin. There were several dark bands between 21.5 to $>36.5 \mathrm{kDa}$ which may correspond to either group 1 or group 5 allergens. Bands were also present in the 55.4 to $66.3 \mathrm{kDa}$ possibly corresponding to group 4 allergens. Upon transfer to nitrocellulose membrane, bands were also seen at the 36.5 and $55.4 \mathrm{kDa}$ (Figure 2), similar to those found in bermuda grass, which may still correspond to group 4 allergens.

Proteins bands in cogon ranged from 3.5 to $200 \mathrm{kDa}$ on gradient SDS-PAGE (Figure 1) which was close to that of Cabauatan and Ramos which ranged from 4.6 to $250 \mathrm{kDa}{ }^{31}$ Most of the bands of cogon were similar to that of carabao grass, except that cogon had bands above 66.3 and near 116.3 $\mathrm{kDa}$. Upon transfer to nitrocellulose membrane, cogon had the most number of bands visible (Figure 2), with a darkstained band above $36.5 \mathrm{kDa}$. The Allergome database lists 5 allergens for cogon (Imp c, Imp c 4, Imp c 5, Imp c 7 and Imp c VIIIe1) but there was none in the WHO-IUIS database. There were 3 previous studies on cogon, all done in India. The first study on cogon characterization showed 24 bands (Coomassie-Brilliant-Blue-stained SDS-PAGE) to 44 bands (silver-stained ELISA-inhibition, thin-layer isoelectric focusing). They detected seven IgE-binding sites on immunoblotting (85 kDa, 62 kDa, 57 kDa, 43 kDa, 40 kDa, 28 $\mathrm{kDa}$, and $16 \mathrm{kDa}) \cdot{ }^{37}$ Two studies purified and characterized 
the Imp c VIIe1, which is a $67 \mathrm{kDa}$ protein. ${ }^{38,39}$ The band visible at $>66.3 \mathrm{kDa}$ in our gradient SDS-PAGE in Figure 1 may correspond to Imp c VIIe1.

Talahib protein bands were in the 21.5 to $66.3 \mathrm{kDa}$ range on gradient SDS-PAGE. It had the least number of bands, 2 of which were lightly-stained and diffuse. Upon transfer to nitrocellulose membrane, there was one prominent band at $66.3 \mathrm{kDa}$ which may correspond to a group 4 grass allergen. The study of Cabauatan and Ramos had 3 prominent bands at 12, 20 and $60 \mathrm{kDa} .^{31}$ There are 3 allergens for talahib listed in the Allergome database (Sac sp, Sac sp13, and Sac sp 7) and again none in the WHO-IUIS database.

The protein bands isolated in this study seem to correspond to certain groups of grass allergens, mostly the major allergens. To confirm this, an immunoblot of the protein components with monoclonal antibodies against the known groups of grass allergens may be done in future studies.

Discrepancies in the number of bands have been noted even in the other studies and may be attributed to differences in pollen extracts, the concentrations of the gels, the accuracy of molecular weight standards, or the sensitivity of the detection system. ${ }^{40}$

By immunoblotting, IgE-binding fractions of the allergen can be detected using the sera of allergic patients. Due to budget constraints, this study was not able to proceed with immunoblot using several sera from grass pollen-allergic patients. Only an initial immunoblot was done with serum from one volunteer with allergic rhinitis who had a strongly positive reaction to bermuda grass and cogon. Immunoblot revealed an IgE-binding fraction at 55.4 $\mathrm{kDa}$ for both bermuda grass and cogon. This may signify a cross-reactivity between bermuda grass and cogon at this protein fraction but further studies from several patient sera have to be done to further prove this. IgE immunoblot inhibition can also be done to confirm cross-reactivity. The procedure is similar to IgE inhibition except that the serum is pre-incubated with an allergen extract presumed to crossreact with the allergen extract being tested. If they are crossreactive, no bands will be seen since the $\operatorname{IgE}$ in the serum is already occupied by the cross-reactive allergen.

\section{Conclusion}

Allergen extracts from four Philippine grass pollen grains were processed into allergen extracts. Protein contents of the extracts ranged from 281.3 to $968.61 \mu \mathrm{g} / \mathrm{ml}$. The protein concentration of the extract did not have any effect on its ability to be resolved into protein components on gradient SDS-PAGE. The protein bands of bermuda grass were in the 14.4 to $66.3 \mathrm{kDa}$ range, carabao grass at 3.5 to $66.3 \mathrm{kDa}$, cogon at 3.5 to $200 \mathrm{kDa}$, and talahib at 21.5 to 66.3 $\mathrm{kDa}$. All four grasses had common bands with molecular weights between 55.4 to $66.3 \mathrm{kDa}$. The bands may correspond to the known groups of major grass allergens, particularly the group 4 grass allergens. Upon immunoblot with serum from a volunteer with positive skin test to bermuda grass and cogon, a single IgE-binding protein band was seen with a molecular weight of $55.4 \mathrm{kDa}$ for both bermuda grass and cogon.

\section{Recommendations}

This study will provide a basis for further pollen characterization studies in the Philippines where data are still lacking and for the manufacture of better quality pollen allergen extracts in the country. Further physicochemical characterization, such as isoelectric focusing and glycoprotein detection using PAS technique, may be done.

Immunoblot using sera from several patients allergic to these pollen extracts is recommended in order to identify the IgE-binding proteins. These IgE-binding fragments can then be purified and subjected to immunoblot against known monoclonal antibodies to the different groups of grass allergens.

Liquid chromatography tandem mass spectrometry (LC-MS/MS) study of the separated bands can be done to identify the protein sequence of the IgE-binding molecules of the pollen extracts studied.

\section{Acknowledgements}

This work was supported by a grant from the National Institutes for Health, University of the Philippines-Manila [NIH (TRB) 2004-010]. Sincere thanks to United Laboratories, Inc. and Alexander O. Tuazon, MD for the technical support and assistance.

\section{References}

1. Beasley R, Keil U, von Mutius E, et al (ISAAC Writing Committee). Worldwide variation in prevalence of symptoms of asthma, allergic rhinoconjunctivitis, and atopic eczema: ISAAC. Lancet. 1998; 351(9111):1225-32.

2. Cua-Lim F, Roa C, Ferreria M, et al. Prevalence of asthma in Metro Manila, Philippines. Phil J Allergy Immunol. 1997; 4(1):9-20.

3. Abong JM, Kwong SL, Alava HA, Castor MR, De Leon JC. Prevalence of allergic rhinitis in Filipino adults based on the National Health and Nutrition Survey (NNHeS) 2008. Asia Pac Allergy. 2012; 2(2):129-35.

4. Varona LL, Alava HA, Abong JM, Castor MR, De Leon JC, Kwong SL. Prevalence of asthma among Filipino adults based on the National Health and Nutrition Survey (NNHeS) 2008. Philipp J Intern Med. 2014; 52(4):1-7.

5. Castillo-Ochoa A, Agbayani BF. The seasonal incidence of bronchial asthma: a preliminary report. I. The relationship of asthma consults with pollen count. Philipp J Intern Med. 1968; 6(4):165-9.

6. D'Amato G, Cecchi L, Bonini S, et al. Allergenic pollen and pollen allergy in Europe. Allergy. 2007; 62(9):976-90.

7. Fischer S, Grote M, Fahlbusch B, Müller WD, Kraft D, Valenta R. Characterization of Phl p 4, a major timothy grass (Phleum pratense) pollen allergen. J Allergy Clin Immunol. 1996; 98(1):189-98.

8. Agbayani BF. Pollenosis in the Philippines. Acta Med Philipp. 1988; 24(3):99-105.

9. Agbayani BF, Lim H, Bulalacao LJ. A study of Philippine common allergenic pollen grains IV. allergenicity studies of isolated pollens by skin tests. Philipp J Intern Med. 1989; 27(4):215-20.

10. Cua-Lim F, Laserna G, Payawal PC. Studies on atmospheric pollens in the Philippines. Ann Allergy. 1978; 40(2): 117-23. 
11. Mandal J, Roy I, Gupta-Bhattacharya S. Clinical and immunobiochemical characterization of airborne Peltophorum pterocarpum (yellow gulmohar tree) pollen: a dominant avenue tree of India. Ann Allergy Asthma Immunol. 2011; 106(5):412-20.

12. Linhart B, Hartl A, Jahn-Schmid B, et al. A hybrid molecule resembling the epitope spectrum of grass pollen for allergy vaccination. J Allergy Clin Immunol. 2005; 115(5):1010-6.

13. Mari A. When does a protein become an allergen? Searching for a dynamic definition based on most advanced technology tools. Clin Exp Allergy. 2008; 38(7):1089-94.

14. Cirkovik Velickvik T, Gavrovic-Jankulovic M, Jankov RM. Overview of the most commonly used methods in allergen characterization. J Serb Chem Soc 2005; 70(3):347-60.

15. Fernandez-Caldas E, Zakzuk J, Lockey RF. Allergen standardization and characterization. [Online]. 2009 [cited 2016 March]. Available from: http://www.worldallergy.org/professional/allergic_diseases_center/aller gen_standardization/.

16. Martin BG, Mansfield LE, Nelson HS. Cross-allergenicity among the grasses. Ann Allergy. 1985; 54(2):99-104.

17. Li JT, Lockey RF, Bernstein IL, et al. Allergen immunotherapy: a practice parameter. Ann Allergy Asthma Immunol. 2003; 90:1-40.

18. Van Ree R, van Leeuwen A, Aalberse RC. How far can we simplify in vitro diagnostics for grass pollen allergy? A study with 17 whole pollen extracts and purified natural and recombinant major allergens. J Allergy Clin Immunol. 1998; 102(2):184-90.

19. Weber RW. Patterns of pollen cross-allergenicity. J Allergy Clin Immunol. 2003; 112(2):229-39.

20. Marsh DG, Goodfriend L, King TP, et al. Allergen nomenclature. Allergy. 1988; 43:161-8.

21. World Health Organization - International Union of Immunological Societies (WHO-IUIS) Subcommittee. The Allergen Nomenclature. [Online] [cited 2016 March]. Available from www.allergen.org.

22. Allergome, A Database of Allergenic Molecules [Online]. 2012 [cited 2016 February]. Available from http://www.allergome.org/index.php.

23. Breiteneder H, Chapman MD. Allergen Nomenclature. In: Allergens and Allergen Immunotherapy. [Online] 2014 [cited March 2016]. Available from http://allergen.org/pubs/10_BRP_69_Breiteneder_MDC_Allergen _Nomenclature_2014.pdf.

24. Baldo BA. Standardization of allergens. Allergy. 1983; 38(8):535-46.

25. Santos-Estrella PFR, Recto MT, Castor MR, et al. Skin prick test reactivity to aeroallergens and food allergens among pediatric patients with common allergic diseases. 2012. Unpublished.

26. Cua-Lim F. Aeroallergens in the Philippines. Phil J Aller Immunol. 1994; $1: 43$.
27. Radauer $\mathrm{C}$, Breiteneder $\mathrm{H}$. Pollen allergens are restricted to few protein families and show distinct patterns of species distribution. J Allergy Clin Immunol. 2006; 117(1):141-7.

28. Cook BG, Pengelly BC, Brown SD, et al. Tropical forages: an interactive selection tool. [Online]. 2005 [cited 2016 February]. Available from http://www.tropicalforages.info/key/Forages/Media/Html/index.htm.

29. Moody K, Munroe CE, Lubigan RT, et al. Major Weeds of the Philippines. Laguna, Philippines: Weed Science Society of the Philippines, University of the Philippines at Los Baños, 1984.

30. Concepcion-Garcia F. Morphology of some important anemophilous pollen grains which are suspected to be causing respiratory allergies in the Philippines. Acta Med Philipp. 1955; 11(4):817-52.

31. Cabauatan CR, Ramos JDA. Immunoglobulin-E binding reactivities of natural pollen grain extracts from selected grass species in the Philippines. Asia Pac Allergy. 2012; 2(2):136-43.

32. Sander I, Fleischer C, Meurer U, et al. Allergen content of grass pollen preparations for skin prick testing and sublingual immunotherapy. Allergy. 2009; 64(10):1486-92.

33. Weber RW. Cross-reactivity of pollen allergens: impact on allergen immunotherapy. Ann Allergy Asthma Immunol. 2007; 99(3):203-11.

34. Niederberger V, Laffer $S$, Froschl R, et al. IgE antibodies to recombinant pollen allergens (Phl p 1, Phl p 2, Phl p 5, and Bet v 2) account for a high percentage of grass pollen-specific IgE. J Allergy Clin Immunol. 1998; 101(2 Pt 1):258-64.

35. Chang ZN, Tsai LC, Chi CW, et al. Analysis of allergenic components of Bermuda grass pollen by monoclonal antibodies. Allergy. 1991; 46(7):520-8.

36. Chow LP, Chiu LL, Khoo KH, et al. Purification and structural analysis of the novel glycoprotein allergen Cyn d 24, a pathogenesis-related PR1, from Bermuda grass pollen. FEBS J. 2005; 272(24):6218-27.

37. Kumar L, Sridhara S, Singh BP, Gangal SV. Characterization of cogon grass (Imperata cylindrica) pollen extract and preliminary analysis of grass group 1, 4 and 5 homologues using monoclonal antibodies to Phleum pratense. Int Arch Allergy Immunol. 1998; 117(3):174-9.

38. Verma J, Singh BP, Gangal SV, et al. Purification and partial characterization of a $67 \mathrm{kD}$ cross-reactive allergen from Imperata cylindrica pollen extract. Int Arch Allergy Immunol. 2000; 122(4):251-6.

39. Bijli KM, Singh BP, Sridhara $S$, et al. Single step purification and characterization of a $67 \mathrm{kD}$ major allergen from Imperata cylindrica grass pollen extract (Abstract). J Allergy Clin Immunol. 2004; 109:S133.

40. Killian S, McMichael J. The human allergens of mesquite (Prosopis juliflora). Clin Mol Allergy. 2004; 2(1):8. 